\title{
PERFORMANCE ANALYSIS AND MARKET POSITIONING OF LEADING PHARMACEUTICAL COMPANIES IN THE REPUBLIC OF CROATIA*
}

\author{
Marina Gregorić ${ }^{1}$, Dajana Maria Horvat ${ }^{2}$ \& Martina Gregoric ${ }^{3}$
}

UDC / UDK: 657.375:615(497.5)

JEL classification / JEL klasifikacija: L65, D53

DOI: https:// doi.org/10.22589/pi-be/2018.12.2.123

Review / Pregledni rad

Received / Primljeno: September 3, 2018 / 3. rujna 2018.

Accepted for publishing / Prihvaćeno za tisak: November 30, 2018 / 30. studenoga 2018.

\section{Summary}

Financial statements indicate the financial position and performance of a company as well as cash flows in accordance with the definitions and criteria for recognizing assets, liabilities, revenues and expenditures. The purpose of this research paper is to analyse and compare the financial statements of six leading pharmaceutical companies in the Republic of Croatia in order to determine their level of success, performance and market positioning. Market positioning is used to determine the place the company, product or service occupies in the market and in the consumer's mind - whether it is that of a leader, follower, challenger or tamponer.

The aim of the paper is to determine the performance of the leading pharmaceutical companies operating in the Republic of Croatia and their ability to overcome the financial crisis that hit the market in 2009. The methodology used in this paper is analysis, synthesis and desk research. Through the method of vertical, horizontal and fundamental analyses of a period of six years of business, it was possible to determine which company best dealt with the financial crisis. Through the conducted business analysis, the authors determined which company aims to improve its business and thereby achieve a better market position. Results of the research indicate that positioning has determined the com-

The paper was presented at the 3rd International Conference „Business \& Entrepreneurial Economics -BEE2018” which was held in Šibenik from 30 May to 2 June 2018 (www.bee-conference.com)

1 Marina Gregorić, Ph. D., senior lecturer, Polytechnic of Međimurje in Čakovec, Croatia, Čakovec, E-mail: marina.gregoric@mev.hr

2 Dajana Maria Horvat, mag. oec., lecturer, Polytechnic of Međimurje in Čakovec, Croatia, E-mail: dajana. maria.horvat@mev.hr

3 Martina Gregorić, MBA Management, director, Euro Saturnus Ltd, Zagreb, E-mail: gregoricm1@gmail.com 
petitiveness of individual companies and their importance on the market, as well as to which extent the performance itself is related to market positioning. According to research results, PLIVA is the market leader; the most successful and safest pharmaceutical company in the Republic of Croatia, while other companies have the positions of followers, challengers and tamponers.

Key words: Croatian pharmaceutical market, financial analysis, market positioning, performance analysis, pharmaceutical companies.

\section{INTRODUCTION}

Financial statements are the final product of financial accounting and are primarily intended for external users, by which we mean current and potential investors, creditors, the government, government organizations, customers, suppliers and other lenders, stock exchanges, professional institutions, professional associations and so on. The objective of financial statements is to provide information on the financial position of a business entity, which is useful to a wide range of users in making economic decisions. In order for the financial statements to fulfil such important tasks and achieve the intended goals, they should satisfy the quality characteristics, such as understandability, relevance, reliability and comparability (Dražić-Lutilsky, 2010).

The set of financial statements consists of four linked reports that summarize the financial assets, liabilities, profitability and monetary transactions of an enterprise. A complete set of financial statements includes:

1) balance sheet showing the financial position of an enterprise on a specific date, assets held, debt and equity capital;

2) profit and loss account, which indicates the profitability of a company during the past year (or another period);

3) statement of equity, which explains certain changes in the amount of equity capital of a company;

4) statement of cash flows that sums up the cash receipts and cash expenses of the company during the simultaneous period, as well as in the profit and loss account;

5) notes to the financial statements.

The basic purpose of the financial statements is to help users evaluate the financial position, profitability and future prosperity of an enterprise (Meigs, 1999).

The financial statements of the company are summarized information on assets, liabilities, company equity in the balance sheet and income and expense in the income statement. If they are not analysed, these data can lead to incorrect conclusions about the financial position of the company (Shim, 2007). Within the International Accounting Standards, the main objective of financial statements is to provide information on the financial position, performance and changes in the financial position of the com- 
pany, which is useful for a wide range of users in making economic decisions (Tipurić, 2008).

Within a comprehensive business analysis, the full coverage of all information is sought, while the analysis of financial statements is oriented towards value or money information. From this it can be concluded that the analysis of financial statements is focused on quantitative financial information and is often referred to as financial analysis (Dražić-Lutilsky, 2010).

The analysis of financial statements can be described as the process of applying various analytical tools and techniques by which the data from the financial statements are translated into usable relevant management information. It is considered that there are three activities that determine the development of a financial analysis, i.e. financial statements analysis, namely: fiscal management, management accounting and financial accounting. Funds and procedures that are commonly used in the analysis of financial statements are comparative financial statements that allow for changes over time, notice of changes in the index series, structural financial statements, benchmarking, specialized analysis (cash flow forecasts, analysis of changes in the financial position, report on changes in gross profit, analysis of coverage point) (Gulin, 2012).

Fundamental instruments and methods of analysis can be classified into comparative financial statements, structural financial statements and financial indicators. The comparative financial statements that serve as a basis for carrying out horizontal analysis can be considered in the context of comparison. Horizontal analysis seeks to see the tendencies and dynamics of changes in certain positions of the underlying financial statements, judging the success and safety of the business of the observed company based on these changes. Structural financial statements serve as a basis for the implementation of a vertical analysis that provides an insight into the structure of the financial statements. The most important in the analysis are financial indicators, so we are talking about individual, common, indicator systems and aggregate indicators. Considering the time dimension, one set of indicators is the one that includes the consideration of a company's business within a certain period and is based on data from the income statement, while the second group of indicators relates to a specific moment that coincides with the moment of compiling the balance sheet and talks about the financial position of the company at that moment. The main groups of indicators for the analysis of financial statements are liquidity indicators that measure the ability of an enterprise to settle its past due liabilities, indicators of indebtedness that measure how much a company is financed from other sources of funds, activity indicators that measure how efficiently an enterprise uses its resources, indicators of cost-effectiveness measure income and expenditures, i.e. show how much revenue is generated per unit of expenditure, profitability indicators measure return on invested capital, which is considered to be the highest managerial effectiveness and investment indicators that measure the success of investing in ordinary shares. Liquidity, indebtedness and activity indicators relate to business safety, while performance indicators are indicators of economy, profitability and investment, and the safety and business performance are the basic criteria for good business (Gulin, 2012). 
According to the competitive dynamics of the market, we find market leaders, market enthusiasts, market followers or companies that want to retain their share and are not inclined to disturb market relations, and niche-niche companies, which serve small market segments that large companies have neglected. A market leader has the largest share in the relevant product market and usually plays a leading role in the change of prices, introduction of new products, territorial coverage of distribution, and the frequency of promotion (Kottler, 2014)

\section{PHARMACEUTICAL INDUSTRY IN THE REPUBLIC OF CROATIA}

The pharmaceutical industry is a healthcare activity at the primary, secondary and tertiary level of health care in the Republic of Croatia. It is regulated by the Health Care Act, the Pharmaceutical Act, the Medicines Act, the Medical Products Act, the Health Insurance Act and the Institutions Act (Lukovnjak, 2012.). In 1991, the process of privatization of the pharmacy sector and the opening of new pharmacies started. Today in the Republic of Croatia we have about 1100 pharmacies, of which 46 are hospital pharmacies.

The pharmaceutical industry in the Republic of Croatia is one of the sectors of the economy that invests heavily in research and development. The discovery of an innovative antibiotic azithromycin has put Croatia in one of the ten countries in the world that can boast of the development of a brand-new drug. The largest drug manufacturer in the Republic of Croatia is PLIVA, but Belupo and Jadran-Galenic Laboratory have excellent cooperation in the European and American markets. The production of pharmaceutical preparations has a strong trend of growth and a major impact on the production of the entire industry. It is important to mention that there is a total of 50 pharmaceutical companies in Croatia, that the number of employees in this industry is around 4978, and that the share of the pharmaceutical industry in the total export of the country amounts to $3.6 \%$ (Agency for Investments and Competitiveness).

\subsection{PLIVA Ltd}

PLIVA is the largest, leading pharmaceutical company in the Republic of Croatia with a long tradition, but also one of the leading companies in Southeast Europe and the largest exporter with $80 \%$ of exports directed to the markets of Russia, USA and Ukraine. PLIVA is now a member of the Teva Group, whose goal is to improve the quality of life and health protection with drugs that are affordable and of high quality. PLIVA's business involves the production of finished medicines and active pharmaceutical substances, and marketing and sales activities throughout the country, as well as in South-Eastern Europe. Its production facilities in Zagreb specialize in dry medicines, sterile products, creams and fats, while some products are produced in Savski Marof.

PLIVA has been performing research work for 70 years, and in this area has recorded significant successes thanks to the state-of-the-art technology and the scientific methods it possesses. Zagreb is one of the major research centres of the Teva Group 
in terms of generic drugs and substances. Thanks to the FDA, MHRA and the Croatian Agency for Medicinal Products and Medical Devices, PLIVA is ranked among the manufacturers that meet the world's highest quality standards required for the global market (PLIVA Official Page).

\subsection{Belupo Plc}

Belupo d.d. is the second largest pharmaceutical company according to its market share, immediately after PLIVA, and was established in 1971 as part of the PODRAVKA Group. It should be noted that it is the leading pharmaceutical company selling medicines with cardiovascular system effects, nerve effect medicines, and skin effects medicines.

Belupo is a modern pharmaceutical company that strives to be in line with technological, market and developmental perspectives, and seeks to preserve the environment, performing daily checks on wastewaters. Part of their strategy relates to energy conservation and the removal of toxic and dangerous substances. They hire highly educated employees who are regularly sent to various educations to keep pace with innovations, as they deal with generic medicines, they produce and pack medicines under the license of world-renowned manufacturers.

Belupo's largest market is Croatia where it earns $60 \%$ of its earnings, while the remaining share is exported to Poland, Slovenia, Slovakia and Russia. Its most famous products are Ginko, Lupocet, Neofen, Maxi Omega 3 etc. (Official Belupo site).

\subsection{Jadran-Galenic Laboratory}

JGL is a medium-sized company based in Rijeka, which has grown on the foundations of the central laboratory for the production and control of the main and galenic preparations of the pharmacy "Jadran" Rijeka. The company was founded in 1991 as the first fully privatized pharmaceutical company in Croatia. By developing new products and by winning new markets, it has been transformed from a local laboratory into a powerful and fast-growing pharmaceutical company. In 1991, JGL released its first registered drug, Carbo Medicinalis, i.e. active medical charcoal, which is still unavoidable in poisoning therapy as a classic absorbent and antidote.

By investing in employee knowledge and developing new products while closely monitoring customer needs, and by investing in modern technologies of drug design and control, JGL has grown in a relatively brief time from a modest embryo into another important pharmaceutical company in the Republic of Croatia.

In its business policy, JGL focuses its activities on the development of new products and the improvement of products that have been produced from the companies' very beginnings in order to continuously add value to its overall portfolio,

Today, JGL has expanded into many markets, some of which include $\mathrm{BiH}$, Macedonia, Serbia, Kosovo, Armenia, Kazakhstan, Georgia, Azerbaijan, Moldova, Uzbeki- 
stan, Tajikistan, Mongolia, Slovenia, Romania, Turkey, Lithuania, Kuwait, Yemen and others, and in New York they registered a company called JGL North America LLC (Official site JGL).

\subsection{Farmal Plc}

Farmal was established in 1959 and is engaged in the production of top quality generic medicines. Their goal is to offer consumers effective, safe, quality and price-sensitive medicines. In 2011, Farmal became part of the German generic pharmaceutical company Dermapharm AG, which enabled them to expand the production program and create new generic drugs of reliable quality. Since becoming part of Dermapharm, Farmal takes care of the environment and the community in which it operates. Their products have an elevated level of trust in the profession, and with their affordable price they make the optimal choice in health care (Official Farmal Site).

\subsection{Institute of immunology}

The Institute of immunology is the oldest producer of immunobiological drugs in this part of Europe, and has been operating since 1893 when it issued the first vaccine against smallpox (variola major). The Royal Territorial Institute is the predecessor of today's trading company Institute of Immunology Plc, for the production of medicines, pharmaceutical products and scientific research work. In accordance with the decision of the Ministry of Health, the Institute of Immunology Plc produces, imports and distributes vaccines for the Program of Compulsory Vaccination in the Republic of Croatia. With its technique, products and professional staff, the Institute of Immunology can compete in the market of viral and bacterial vaccines globally, and in the area of plasma fractionation regionally. The goal of the Institute is to improve existing products and create new ones (According to the official website of the Institute of Immunology)

\section{RESEARCH RESULTS}

Research was conducted on the five previously mentioned pharmaceutical companies in the Republic of Croatia and the observed period spans from 2011 to 2016. The research was carried out by looking at the financial statements of the companies, i.e. the balance sheet and profit and loss accounts, which were compared structurally and comparatively. An analysis of indicators of liquidity, indebtedness, activity and cost-effectiveness were made based on these financial statements.

By observing PLIVA Ltd we saw that its liquidity was growing by 2014 , and then it fell - in 2015 it fell below 1 meaning that its liabilities were larger than its assets, but the stability coefficient was greatest in 2016. In other words, PLIVA's share of short-term assets were funded by quality long-term sources. Furthermore, its indebtedness coefficient was constantly decreasing as it was about reducing total liabilities, and it was also positive that PLIVA Ltd was constantly recording an increasing share of funding from 
its own sources, while it was less funded by other sources, which is a possible cause of decrease in total liabilities. Activity indicators showed an increase in the revolving coefficient by 2013, while a slight decline was noticed until 2014. However, the coefficients of revolutions were the highest in 2015, and this affected the duration of the collection of claims that was the shortest in 2015 - 115 days. In addition, the economy was the largest in 2016, which leads to a conclusion that PLIVA Ltd is constantly improving its business and recording an ever-increasing market share. PLIVA could position itself as the market leader with the highest share and best business in the pharmaceutical industry.

Table 1: Liquidity indicators of PLIVA Ltd

\begin{tabular}{|c|c|c|c|c|c|c|}
\hline $\begin{array}{c}\text { LIQUIDITY } \\
\text { INDICATORS }\end{array}$ & $\mathbf{2 0 1 1 .}$ & $\mathbf{2 0 1 2 .}$ & $\mathbf{2 0 1 3 .}$ & $\mathbf{2 0 1 4}$ & $\mathbf{2 0 1 5 .}$ & $\mathbf{2 0 1 6 .}$ \\
\hline $\begin{array}{c}\text { Cash coverage } \\
\text { coefficient }\end{array}$ & 0,067 & 0,204 & 0,055 & 0,060 & 0,019 & 0,007 \\
\hline Quick coefficient & 1,561 & 1,811 & 2,423 & 2,494 & 0,879 & 0,585 \\
\hline Current coefficient & 1,942 & 2,475 & 3,455 & 3,355 & 1,634 & 1,052 \\
\hline Stability coefficient & 0,629 & 0,661 & 0,686 & 0,652 & 0,855 & 0,967 \\
\hline
\end{tabular}

Source: created by authors

Table 2: Debt indicators of PLIVA Ltd

\begin{tabular}{|c|c|c|c|c|c|c|}
\hline DEBT INDICATORS & 2011. & 2012. & 2013. & 2014. & 2015. & 2016. \\
\hline Indebtedness coefficient & 0,625 & 0,532 & 0,475 & 0,546 & 0,555 & 0,392 \\
\hline $\begin{array}{c}\text { Own financing } \\
\text { coefficient }\end{array}$ & 0,375 & 0,468 & 0,525 & 0,454 & 0,445 & 0,608 \\
\hline Financing coefficient & 1,664 & 1,138 & 0,904 & 1,202 & 1,245 & 0,645 \\
\hline
\end{tabular}

Source: created by authors

Table 3: Activity indicators of PLIVA Ltd

\begin{tabular}{|c|c|c|c|c|c|c|}
\hline $\begin{array}{c}\text { ACTIVITY } \\
\text { INDICATORS }\end{array}$ & $\mathbf{2 0 1 1 .}$ & $\mathbf{2 0 1 2}$ & $\mathbf{2 0 1 3}$ & $\mathbf{2 0 1 4}$ & $\mathbf{2 0 1 5}$ & $\mathbf{2 0 1 6 .}$ \\
\hline $\begin{array}{c}\text { Revolving coefficient of } \\
\text { total assets }\end{array}$ & 0,339 & 0,414 & 0,402 & 0,422 & 0,526 & 0,650 \\
\hline $\begin{array}{c}\text { Revolving coefficient of } \\
\text { short-term assets }\end{array}$ & 0,618 & 0,914 & 1,026 & 0,978 & 1,727 & 1,584 \\
\hline $\begin{array}{c}\text { Revolving coefficient of } \\
\text { claims }\end{array}$ & 0,760 & 1,329 & 1,458 & 1,298 & 3,183 & 2,775 \\
\hline $\begin{array}{c}\text { Duration of payment in } \\
\text { days }\end{array}$ & $\begin{array}{c}480,4 \\
34\end{array}$ & $\begin{array}{c}274,6 \\
73\end{array}$ & $\begin{array}{c}250,3 \\
48\end{array}$ & $\begin{array}{c}281,2 \\
08\end{array}$ & $\begin{array}{c}114,6 \\
62\end{array}$ & $\begin{array}{c}131,5 \\
39\end{array}$ \\
\hline
\end{tabular}

Source: created by authors 
Table 4: Economic indicators of PLIVA Ltd

\begin{tabular}{|c|c|c|c|c|c|c|}
\hline $\begin{array}{c}\text { ECONOMIC } \\
\text { INDICATORS }\end{array}$ & $\mathbf{2 0 1 1 .}$ & $\mathbf{2 0 1 2 .}$ & $\mathbf{2 0 1 3}$ & $\mathbf{2 0 1 4}$ & $\mathbf{2 0 1 5 .}$ & $\mathbf{2 0 1 6 .}$ \\
\hline $\begin{array}{c}\text { Economics of Total } \\
\text { Business }\end{array}$ & 1,046 & 1,204 & 1,084 & 1,170 & 1,059 & 1,202 \\
\hline Economics of Sales & 1,227 & 1,243 & 1,148 & 1,241 & 1,158 & 1,218 \\
\hline Economics of Financing & 0,293 & 0,784 & 0,356 & 0,476 & 0,282 & 0,899 \\
\hline
\end{tabular}

Source: created by authors

The highest liquidity of Belupo Plc was recorded in 2011, followed by a constant decline, while the financial stability coefficient was the highest in 2016, just as in the case of Pliva Ltd. Indebtedness was constantly at approximately the same level, although 2016 stands out as the year with the highest indebtedness. Furthermore, funding through its own resources reduced with the increase of funding from other sources. Coefficients of trade grew steadily while billing time was the shortest in 2015 - 182 days, and in other years it exceeded 200 days. Its economy was the largest in 2012, while a significant decline in economy took place in 2013. From 2013 until 2016, economic growth was recorded, and it reached approximately the same value as in 2012.

Table 5: Liquidity indicators of Belupo Plc

\begin{tabular}{|c|c|c|c|c|c|c|}
\hline $\begin{array}{c}\text { LIQIUDITY } \\
\text { INDICATORS }\end{array}$ & $\mathbf{2 0 1 1 .}$ & $\mathbf{2 0 1 2}$. & $\mathbf{2 0 1 3}$ & $\mathbf{2 0 1 4}$ & $\mathbf{2 0 1 5}$. & $\mathbf{2 0 1 6 .}$ \\
\hline $\begin{array}{c}\text { Cash coverage } \\
\text { coefficient }\end{array}$ & 0,101 & 0,107 & 0,105 & 0,214 & 0,315 & 0,223 \\
\hline Quick coefficient & 1,615 & 1,576 & 1,420 & 1,528 & 1,476 & 1,185 \\
\hline Current coefficient & 2,024 & 1,986 & 1,760 & 2,001 & 2,045 & 1,632 \\
\hline Stability coefficient & 0,606 & 0,594 & 0,633 & 0,609 & 0,722 & 0,836 \\
\hline
\end{tabular}

Source: created by authors

Table 6: Debt indicators of Belupo Plc

\begin{tabular}{|c|c|c|c|c|c|c|}
\hline DEBT INDICATORS & $\mathbf{2 0 1 1 .}$ & $\mathbf{2 0 1 2}$ & $\mathbf{2 0 1 3}$ & $\mathbf{2 0 1 4}$ & $\mathbf{2 0 1 5}$ & $\mathbf{2 0 1 6 .}$ \\
\hline $\begin{array}{c}\text { Indebtedness } \\
\text { coefficient }\end{array}$ & 0,422 & 0,352 & 0,333 & 0,352 & 0,420 & 0,480 \\
\hline $\begin{array}{c}\text { Own financing } \\
\text { coefficient }\end{array}$ & 0,578 & 0,648 & 0,667 & 0,648 & 0,518 & 0,520 \\
\hline Financing coefficient & 0,729 & 0,544 & 0,499 & 0,544 & 0,506 & 0,923 \\
\hline
\end{tabular}

Source: created by authors 
Table 7: Activity indicators of Belupo Plc

\begin{tabular}{|c|c|c|c|c|c|c|}
\hline $\begin{array}{c}\text { ACTIVITY } \\
\text { INDICATORS }\end{array}$ & $\mathbf{2 0 1 1 .}$ & $\mathbf{2 0 1 2}$ & $\mathbf{2 0 1 3}$ & $\mathbf{2 0 1 4}$ & $\mathbf{2 0 1 5}$ & $\mathbf{2 0 1 6 .}$ \\
\hline $\begin{array}{c}\text { Revolving coefficient } \\
\text { of total assets }\end{array}$ & 0,613 & 0,626 & 0,666 & 0,666 & 0,490 & 0,396 \\
\hline $\begin{array}{c}\text { Revolving coefficient } \\
\text { of short-term assets }\end{array}$ & 1,091 & 1,080 & 1,162 & 1,184 & 1,140 & 1,179 \\
\hline $\begin{array}{c}\text { Revolving coefficient } \\
\text { of claims }\end{array}$ & 1,449 & 1,448 & 1,547 & 1,797 & 1,996 & 1,939 \\
\hline $\begin{array}{c}\text { Duration of payment } \\
\text { in days }\end{array}$ & $\begin{array}{c}251,91 \\
6\end{array}$ & $\begin{array}{c}252,1 \\
14\end{array}$ & $\begin{array}{c}235,9 \\
25\end{array}$ & $\begin{array}{c}203,1 \\
34\end{array}$ & $\begin{array}{c}182,8 \\
91\end{array}$ & $\begin{array}{c}188,2 \\
25\end{array}$ \\
\hline
\end{tabular}

Source: created by authors

Table 8: Economic indicators of Belupo Plc

\begin{tabular}{|c|c|c|c|c|c|c|}
\hline $\begin{array}{c}\text { ECONOMIC } \\
\text { INDICATORS }\end{array}$ & $\mathbf{2 0 1 1 .}$ & $\mathbf{2 0 1 2}$ & $\mathbf{2 0 1 3}$ & $\mathbf{2 0 1 4}$ & $\mathbf{2 0 1 5}$ & $\mathbf{2 0 1 6 .}$ \\
\hline $\begin{array}{c}\text { Economics of Total } \\
\text { Business }\end{array}$ & 1,178 & 1,172 & 1,181 & 1,118 & 1,022 & 1,152 \\
\hline Economics of Sales & 2,227 & 2,121 & 2,152 & 2,220 & 1,898 & 2,246 \\
\hline $\begin{array}{c}\text { Economics of } \\
\text { Financing }\end{array}$ & 0,202 & 0,328 & 0,042 & 0,036 & 0,071 & 0,260 \\
\hline
\end{tabular}

Source: created by authors

In the case of JGL Plc, the highest current liquidity was in 2014, and the highest current liquidity exceeded 3 in 2015. Business stability was the highest in 2014 but the stability coefficient does not record significant changes in all the six years included in the study, which leads to a conclusion that the business can be characterized by a constant stability. As far as debts are concerned, it was constant until funding from own resources decreased by 206 , while funding from other sources increased. The problem with JGL was in the issue of the collection of claims - the time span increased steadily and in 2016 amounted to 317 days. The overall economy of business and the economy was the lowest in 2015, while it was the highest in 2011, with the reverse being true in the case of the economy of financing.

Table 9: Liquidity indicators of JGL Plc

\begin{tabular}{|c|c|c|c|c|c|c|}
\hline $\begin{array}{c}\text { LIQUIDITY } \\
\text { INDICATORS }\end{array}$ & $\mathbf{2 0 1 1 .}$ & $\mathbf{2 0 1 2}$ & $\mathbf{2 0 1 3}$ & $\mathbf{2 0 1 4}$ & $\mathbf{2 0 1 5}$ & $\mathbf{2 0 1 6 .}$ \\
\hline $\begin{array}{c}\text { Cash coverage } \\
\text { coefficient }\end{array}$ & 0,007 & 0,048 & 0,038 & 0,053 & 0,049 & 0,050 \\
\hline Quick coefficient & 1,245 & 1,653 & 1,945 & 1,290 & 2,294 & 2,283 \\
\hline Current coefficient & 1,973 & 2,300 & 2,651 & 2,051 & 3,488 & 2,894 \\
\hline Stability coefficient & 0,547 & 0,523 & 0,516 & 0,646 & 0,624 & 0,629 \\
\hline
\end{tabular}

Source: created by authors 
Table 10: Debt indicators of JGL Plc

\begin{tabular}{|c|c|c|c|c|c|c|}
\hline DEBT INDICATORS & $\mathbf{2 0 1 1 .}$ & $\mathbf{2 0 1 2 .}$ & $\mathbf{2 0 1 3 .}$ & $\mathbf{2 0 1 4}$ & $\mathbf{2 0 1 5 .}$ & $\mathbf{2 0 1 6 .}$ \\
\hline $\begin{array}{c}\text { Indebtedness } \\
\text { coefficient }\end{array}$ & 0,621 & 0,612 & 0,569 & 0,598 & 0,625 & 0,607 \\
\hline $\begin{array}{c}\text { Own financing } \\
\text { coefficient }\end{array}$ & 0,366 & 0,379 & 0,413 & 0,380 & 0,356 & 0,328 \\
\hline Financing coefficient & 1,699 & 1,615 & 1,379 & 1,573 & 1,755 & 1,851 \\
\hline
\end{tabular}

Source: created by authors

Table 11: Activity indicators of JGL Plc

\begin{tabular}{|c|c|c|c|c|c|c|}
\hline $\begin{array}{c}\text { ACTIVITY } \\
\text { INDICATORS }\end{array}$ & $\mathbf{2 0 1 1 .}$ & $\mathbf{2 0 1 2 .}$ & $\mathbf{2 0 1 3 .}$ & $\mathbf{2 0 1 4 .}$ & $\mathbf{2 0 1 5 .}$ & $\mathbf{2 0 1 6 .}$ \\
\hline $\begin{array}{c}\text { Revolving coefficient of } \\
\text { total assets }\end{array}$ & 0,721 & 0,741 & 0,729 & 0,584 & 0,545 & 0,517 \\
\hline $\begin{array}{c}\text { Revolving coefficient of } \\
\text { short-term assets }\end{array}$ & 1,153 & 1,208 & 1,209 & 1,095 & 1,165 & 0,987 \\
\hline $\begin{array}{c}\text { Revolving coefficient of } \\
\text { claims }\end{array}$ & 1,803 & 1,673 & 1,627 & 1,672 & 1,541 & 1,152 \\
\hline $\begin{array}{c}\text { Duration of payment in } \\
\text { days }\end{array}$ & $\begin{array}{c}202,40 \\
0\end{array}$ & $\begin{array}{c}218,1 \\
26\end{array}$ & $\begin{array}{c}224,2 \\
83\end{array}$ & $\begin{array}{c}218,3 \\
49\end{array}$ & $\begin{array}{c}236,9 \\
12\end{array}$ & $\begin{array}{c}316,9 \\
64\end{array}$ \\
\hline
\end{tabular}

Source: created by authors

Table 12: Economic indicators of JGL Plc

\begin{tabular}{|c|c|c|c|c|c|c|}
\hline $\begin{array}{c}\text { ECONOMIC } \\
\text { INDICATORS }\end{array}$ & $\mathbf{2 0 1 1 .}$ & $\mathbf{2 0 1 2 .}$ & $\mathbf{2 0 1 3 .}$ & $\mathbf{2 0 1 4}$ & $\mathbf{2 0 1 5}$ & $\mathbf{2 0 1 6 .}$ \\
\hline $\begin{array}{c}\text { Economics of Total } \\
\text { Business }\end{array}$ & 1,156 & 1,127 & 1,109 & 1,038 & 1,034 & 1,130 \\
\hline Economics of Sales & 1,212 & 1,174 & 1,146 & 1,126 & 1,090 & 1,288 \\
\hline $\begin{array}{c}\text { Economics of } \\
\text { Financing }\end{array}$ & 0,328 & 0,522 & 0,552 & 0,540 & 0,800 & 0,537 \\
\hline
\end{tabular}

Source: created by authors

Farmal Plc faced the biggest problems as all indicators pointed to business difficulties. Current liquidity was the only indicator that was on the rise, while all other indicators of liquidity were constantly falling. The company was mostly funded from other sources and became increasingly indebted. Reverse coefficients also declined, and the duration of the billing increased as the economy slowed down. All indicators pointed to grave problems that Farmal encountered and these must be tackled in order to prevent the company's failure. The biggest problem is the negative business that is most readily seen in the profit and loss account which constantly recorded losses and was transmitted to the "equity and provision" balance sheet. 
Table 13: Liquidity indicators of Farmal Plc

\begin{tabular}{|c|c|c|c|c|c|c|}
\hline $\begin{array}{c}\text { LIQUIDITY } \\
\text { INDICATORS }\end{array}$ & $\mathbf{2 0 1 1}$. & $\mathbf{2 0 1 2 .}$ & $\mathbf{2 0 1 3}$. & $\mathbf{2 0 1 4}$ & $\mathbf{2 0 1 5}$ & $\mathbf{2 0 1 6 .}$ \\
\hline $\begin{array}{c}\text { Cash coverage } \\
\text { coefficient }\end{array}$ & 0,009 & 0,011 & 0,035 & 0,041 & 0,030 & 0,047 \\
\hline $\begin{array}{c}\text { Quick } \\
\text { coefficient }\end{array}$ & 0,337 & 0,363 & 0,748 & 0,678 & 3,509 & 0,377 \\
\hline $\begin{array}{c}\text { Current } \\
\text { coefficient }\end{array}$ & 0,668 & 0,645 & 1,140 & 1,175 & 0,752 & 0,520 \\
\hline $\begin{array}{c}\text { Stability } \\
\text { coefficient }\end{array}$ & 1,653 & 2,639 & 1,019 & 0,940 & 1,639 & 6,561 \\
\hline
\end{tabular}

Source: created by authors

Table 14: Debt indicators of Farmal Plc

\begin{tabular}{|c|c|c|c|c|c|c|}
\hline $\begin{array}{c}\text { DEBT } \\
\text { INDICATORS }\end{array}$ & $\mathbf{2 0 1 1 .}$ & $\mathbf{2 0 1 2 .}$ & $\mathbf{2 0 1 3 .}$ & $\mathbf{2 0 1 4}$ & $\mathbf{2 0 1 5 .}$ & $\mathbf{2 0 1 6 .}$ \\
\hline $\begin{array}{c}\text { Indebtedness } \\
\text { coefficient }\end{array}$ & 1,120 & 1,220 & 1,459 & 1,746 & 2,374 & 2,067 \\
\hline $\begin{array}{c}\text { Own financing } \\
\text { coefficient }\end{array}$ & $-0,130$ & $-0,239$ & $-0,542$ & $-0,797$ & $-1,410$ & $-1,106$ \\
\hline $\begin{array}{c}\text { Financing } \\
\text { coefficient }\end{array}$ & $-8,608$ & $-5,110$ & $-2,693$ & $-2,190$ & $-1,684$ & $-1,869$ \\
\hline
\end{tabular}

Source: created by authors

Table 15: Activity indicators of Farmal Plc

\begin{tabular}{|c|c|c|c|c|c|c|}
\hline $\begin{array}{c}\text { ACTIVITY } \\
\text { INDICATORS }\end{array}$ & $\mathbf{2 0 1 1}$ & $\mathbf{2 0 1 2}$ & $\mathbf{2 0 1 3}$ & $\mathbf{2 0 1 4}$ & $\mathbf{2 0 1 5}$ & $\mathbf{2 0 1 6 .}$ \\
\hline $\begin{array}{c}\text { Revolving coefficient } \\
\text { of total assets }\end{array}$ & 0,957 & 0,981 & 0,682 & 0,546 & 0,051 & 0,051 \\
\hline $\begin{array}{c}\text { Revolving coefficient } \\
\text { of short-term assets }\end{array}$ & 2,168 & 1,903 & 1,248 & 1,009 & 0,104 & 0,104 \\
\hline $\begin{array}{c}\text { Revolving coefficient } \\
\text { of claims }\end{array}$ & 4,228 & 3,420 & 1,924 & 1,719 & 0,204 & 0,204 \\
\hline $\begin{array}{c}\text { Duration of payment in } \\
\text { days }\end{array}$ & 86,337 & $\begin{array}{c}106,7 \\
12\end{array}$ & $\begin{array}{c}189,7 \\
24\end{array}$ & $\begin{array}{c}212,2 \\
80\end{array}$ & $\begin{array}{c}1791, \\
953\end{array}$ & $\begin{array}{c}1791,9 \\
53\end{array}$ \\
\hline
\end{tabular}

Source: created by authors

Table 16: Economic indicators of Farmal Plc

\begin{tabular}{|c|c|c|c|c|c|c|}
\hline $\begin{array}{c}\text { ECONOMIC } \\
\text { INDICATORS }\end{array}$ & $\mathbf{2 0 1 1}$ & $\mathbf{2 0 1 2}$ & $\mathbf{2 0 1 3}$ & $\mathbf{2 0 1 4}$. & $\mathbf{2 0 1 5 .}$ & $\mathbf{2 0 1 6 .}$ \\
\hline $\begin{array}{c}\text { Economics of Total } \\
\text { Business }\end{array}$ & 0,910 & 0,904 & 0,709 & $-0,732$ & $-0,058$ & $-1,556$ \\
\hline Economics of Sales & 0,987 & 1,011 & 0,841 & $-8,010$ & $-5,585$ & $-1,595$ \\
\hline $\begin{array}{c}\text { Economics of } \\
\text { Financing }\end{array}$ & 0,101 & 0,046 & 0,063 & $-0,096$ & $-0,204$ & $-0,710$ \\
\hline
\end{tabular}

Source: created by authors 
With regard to the Institute of Immunology, its liquidity indicators indicate a constant reduction in liquidity, but also an increase in stability that occurred due to a reduction in long-term liabilities and the amount of capital. Indebtedness coefficients increased and point to a reduction in funding from their own sources. Coefficients of revolutions have also reduced over time, while billing time was longest in 2015 when it amounted to 148 days and the shortest in 2011 - 60 days. The economy of the entire business operations of the Immunological Institute was constantly decreasing until 2016, while at that time the economy of sales and financing was the largest.

Table 17: Liquidity indicators of Institute of Immunology

\begin{tabular}{|c|c|c|c|c|c|c|}
\hline $\begin{array}{c}\text { LIQIDITY } \\
\text { INDICATORS }\end{array}$ & $\mathbf{2 0 1 1 .}$ & $\mathbf{2 0 1 2 .}$ & $\mathbf{2 0 1 3 .}$ & $\mathbf{2 0 1 4 .}$ & $\mathbf{2 0 1 5 .}$ & $\mathbf{2 0 1 6 .}$ \\
\hline $\begin{array}{c}\text { Cash coverage } \\
\text { coefficient }\end{array}$ & 0,024 & 0,028 & 0,059 & 0,003 & 0,003 & 0,002 \\
\hline $\begin{array}{c}\text { Quick } \\
\text { coefficient }\end{array}$ & 0,245 & 0,459 & 0,263 & 0,056 & 0,044 & 0,051 \\
\hline $\begin{array}{c}\text { Current } \\
\text { coefficient }\end{array}$ & 0,955 & 1,158 & 0,722 & 0,396 & 0,336 & 0,277 \\
\hline $\begin{array}{c}\text { Stability } \\
\text { coefficient }\end{array}$ & 1,019 & 0,950 & 1,102 & 1,391 & 1,487 & 1,598 \\
\hline
\end{tabular}

Source: created by authors

Table 18: Debt indicators of Institute of Immunology

\begin{tabular}{|c|c|c|c|c|c|c|}
\hline DEBT & $\mathbf{2 0 1 1}$ & $\mathbf{2 0 1 2}$ & $\mathbf{2 0 1 3}$ & $\mathbf{2 0 1 4}$ & $\mathbf{2 0 1 5 .}$ & $\mathbf{2 0 1 6 .}$ \\
\hline $\begin{array}{c}\text { INDICATORS } \\
\text { coefficieient }\end{array}$ & 0,401 & 0,499 & 0,549 & 0,625 & 0,620 & 0,607 \\
\hline $\begin{array}{c}\text { Own financing } \\
\text { coefficient }\end{array}$ & 0,599 & 0,501 & 0,451 & 0,375 & 0,380 & 0,393 \\
\hline $\begin{array}{c}\text { Financing } \\
\text { coefficient }\end{array}$ & 0,669 & 0,996 & 1,216 & 1,664 & 1,629 & 1,547 \\
\hline
\end{tabular}

Source: created by authors

Table 19: Activity indicators of Institute of Immunology

\begin{tabular}{|c|c|c|c|c|c|c|}
\hline $\begin{array}{c}\text { ACTIVITY } \\
\text { INDICATORS }\end{array}$ & $\mathbf{2 0 1 1 .}$ & $\mathbf{2 0 1 2}$ & $\mathbf{2 0 1 3}$ & $\mathbf{2 0 1 4 .}$ & $\mathbf{2 0 1 5}$ & $\mathbf{2 0 1 6 .}$ \\
\hline $\begin{array}{c}\text { Revolving coefficient } \\
\text { of total assets }\end{array}$ & 0,392 & 0,277 & 0,223 & 0,100 & 0,049 & $-0,014$ \\
\hline $\begin{array}{c}\text { Revolving coefficient } \\
\text { of short-term assets }\end{array}$ & 1,401 & 1,003 & 1,155 & 0,645 & 0,347 & $-0,109$ \\
\hline $\begin{array}{c}\text { Revolving coefficient } \\
\text { of claims }\end{array}$ & 6,040 & 2,660 & 3,945 & 4,290 & 2,474 & 3,541 \\
\hline $\begin{array}{c}\text { Duration of payment } \\
\text { in days }\end{array}$ & 60,426 & $\begin{array}{c}137,21 \\
3\end{array}$ & 92,526 & 85,074 & $\begin{array}{c}147,55 \\
4\end{array}$ & $\begin{array}{c}103,0 \\
72\end{array}$ \\
\hline
\end{tabular}

Source: created by authors 
Table 20: Economic indicators of Institute of Immunology

\begin{tabular}{|c|c|c|c|c|c|c|}
\hline $\begin{array}{c}\text { ECONOMIC } \\
\text { INDICATORS }\end{array}$ & $\mathbf{2 0 1 1}$ & $\mathbf{2 0 1 2}$ & $\mathbf{2 0 1 3}$ & $\mathbf{2 0 1 4}$ & $\mathbf{2 0 1 5}$ & $\mathbf{2 0 1 6 .}$ \\
\hline $\begin{array}{c}\text { Economics of } \\
\text { Total Business }\end{array}$ & 1,000 & 0,833 & 0,691 & 0,471 & 0,269 & 0,164 \\
\hline $\begin{array}{c}\text { Economics of } \\
\text { Sales }\end{array}$ & 1,056 & 0,884 & 0,774 & 0,491 & 0,276 & 1,178 \\
\hline $\begin{array}{c}\text { Economics of } \\
\text { Financing }\end{array}$ & 0,098 & 0,150 & 0,177 & 0,356 & 0,223 & 0,255 \\
\hline
\end{tabular}

Source: created by authors

By comparing all the observed companies and their liquidity, it is evident that PLIVA has the highest liquidity, which indicates that the company can settle its shortterm liabilities with treasury bills and receivables. The company's short-term liabilities can also be settled in short-term assets and, finally, it is liquid and stable and has enough working capital. Of all the observed companies, PLIVA, JGL and Belupo are liquid and stable companies.

In terms of indebtedness, PLIVA reduced its indebtedness and increased its own capital financing, thereby reducing the financial risk, and is the only company among the observed which has satisfactory indebtedness coefficients. In terms of the cyclization of assets, PLIVA has a satisfactory coefficient of trades, and its billing days are decreasing. Belupo does not rotate its own assets and it almost stagnates, but just like PLIVA, its billing days are declining. The assets of JGL, Immunological Institute and Farmal are virtually non-circulating, and the coefficients of claims trades are declining, their billing days have increased, and they have the biggest problem with collecting receivables. To conclude, in terms of the circulation of assets it can be said that PLIVA is the only company which turns its assets well and reduces the day-to-day collection of claims, while other companies either have problems with collecting receivables or their assets are almost stagnating. The business efficiency of PLIVA is satisfactory as revenues increase and expenditures decrease, which can also be said for its profitability. Belupo is also economical and profitable, while JGL's economy and profitability are declining. The economy and profitability of Farmal and Institute of Immunology are declining.

In conclusion, if we look at the business as a whole, PLIVA is the best because it is liquid, stable, is reducing its indebtedness, is funded mostly from its own equity, is increasing its economy and profitability, and is the only company that has a satisfactory business property coefficient. This company needs the shortest amount of time to collect its receivables and to settle its obligations. The companies that have the worst business are Farmal and the Institute of Immunology, which are neither liquid nor stable nor economical, their assets are virtually non-circulating and it takes these companies the longest time to collect receivables but also to meet their obligations.

Regarding competitive dynamics, PLIVA is a market leader with a largest market share, but it is also the best business to conduct the analysis. Belupo and JGL are the market makers because, even though their business is not as good as PLIVA, their prod- 
ucts take on a large market share and with further development and regulation of their operations, it could seriously threaten PLIVA's leader position. Furthermore, Farmal is a market participant because it has no capacity to threaten PLIVA's leading position, but because of the bad business it has been doing lately, it cannot be a threat to any of the market players. The Institute of Immunology is in the market niche, has a significant role in the market and is solely engaged in the manufacture of vaccines and scientific research which does not endanger the market position of other companies.

\section{CONCLUSION}

A business analysis of an enterprise is important to determine how the business is operating, i.e. whether it is progressing, reversing or stagnating. It is apparent that some things have been concluded at the very beginning of the analysis, i.e. when analysing the comparative and structural financial statements, but a fundamental analysis gave a more detailed picture of the business of each company.

PLIVA is the strongest and most successful pharmaceutical company in the Republic of Croatia, and this is evident from this analysis. Both Jadran - Galenic Laboratory and Belupo are liquid, but unlike Belupo, JGL is increasing its liquidity. In addition, PLIVA is reducing its indebtedness and is increasingly financed from its own resources, while most other companies, such as the Institute of Immunology and Farmal, are becoming more and more indebted and almost entirely not funded from their own resources. Furthermore, PLIVA is increasing its economy and profitability and is a company to invest in, as it is the safest pharmaceutical company in the Republic of Croatia with a tendency of growth. The worst business is recorded by Farmal and the Institute of Immunology. The Institute of Immunology is an enterprise with low liquidity, not economical or profitable. Funding from its own resources is minimal, and borrowing is extensive. The list of shortcomings is long, and it is not surprising that the company has trouble paying wages to its employees.

Regarding Belupo and JGL, their business is satisfactory, and perhaps some minor changes in business could make these companies become a strong competitor of Pliva.

As expected, PLIVA, Belupo and JGL, which are best-known pharmaceutical companies in the Republic of Croatia, have the best business and are the most prominent in the market, while Farmal is poorly operating. As far as Institute of Immunology is concerned, its business could be improved, but extensive investment and change in its business needs to be done, because constant borrowing has led the company to its present situation. 


\section{REFERENCES:}

1. Agency for Investments and Competitiveness, Pharmacy. URL: http://www.aik-invest.hr/sektori/farmacija/, 10.3.2018.

2. Belupo Official Page. URL: http://www.belupo.hr/, 14.02.2018.

3. Dražić-Lutilsky I., Gulin D., Mamić-Sačer I., Tadijančević S., Tušek B., Vašiček V., Žager K., Žager L. (2010.) Računovodstvo (3. izmijenjeno izdanje). Zagreb: Hrvatska zajednica računovođa i financijskih djelatnika

4. Farmal Official Page. URL: http://www.farmal.hr/, 15.02.2018.

5. Gulin D., Perčević H., Tušek B., Žager L. (2012.) Poslovno planiranje, kontrola $i$ analiza. Zagreb: Hrvatska zajednica računovođa i financijskih djelatnika

6. Immunological Institute Official Page. URL: http://www.imz.hr/o-nama.php, 14.02.2018.

7. JGL Official Page. URL: http://www.jgl.hr/hr/o-jgl/ , 14.02.2018.

8. Kottler P., Lane Keller K., Martinović M. (2014.) Upravljanje marketingom, Zagreb: Mate d.o.o.

9. Lukovnjak I., Takač D., Portolan M., (2012.) Hrvatsko ljekarništvo - organizaci$j a$, poslovanje $i$ strategija razvoja. Udruženja farmaceuta regije Zagreb. Šibenik. URL: http://www.hfd-fg.hr/dokumenti/X_savjetovanje_farmaceuta/petak-25.05.2012/03/Hrvatsko\%20ljekarnistvo-organizacija,\%20poslovanje\%20i\%20 strategija\%20razvoja.pdf,

10. Meigs F. R., Meigs B. W. (1999.) Računovodstvo: Temelj poslovnog odlučivanja (9. izdanje). Zagreb: Mate

11. PLIVA Official Page. URL: http://www.pliva.hr/pliva/podaci-o-kompaniji , 15.02.2018.

12. Shim J. K., Siegel J. G. (2007.) Upravljačke financije. Zagreb: Zombić \& Partneri

13. Tipurić D. i sur. (2008.) Korporativno upravljanje. Zagreb: Sinergija 


\title{
ANALIZA POSLOVANJA I POLOŽAJA NA TRŽIŠTU VODEĆIH FARMACEUTSKIH KOMPANIJA U REPUBLICI HRVATSKOJ ${ }^{\star}$
}

\author{
Marina Gregorić ${ }^{4}$, Dajana Maria Horvat ${ }^{5}$ \& Martina Gregorić ${ }^{6}$
}

\section{Sažetak}

Financijski izvještaji ukazuju na financijski položaj i uspješnost poslovanja te novčane tijekove u skladu s definicijama i kriterijima za priznavanje imovine, obveza, prihoda i rashoda. Svrha ovog istraživačkog rada jest analizirati i usporediti financijska izvješća šest vodećih farmaceutskih tvrtki u Republici Hrvatskoj kako bi se utvrdila njihova razina uspjeha, uspješnosti i tržišnog pozicioniranja. Pozicioniranje na tržištu koristi se za određivanje mjesta koje tvrtka, proizvod ili usluga zauzima na tržištu i u smislu potrošača; voditelj, sljedbenik, izazivač ili tamponer.

Cilj rada je utvrditi uspješnost vodećih farmaceutskih tvrtki koje djeluju u Republici Hrvatskoj i njihovu sposobnost da prevladaju financijsku krizu koja je 2009. godine pogodila tržište. Metodologija korištena u ovom radu je analiza, sinteza i metoda istraživanja za stolom. Kroz metodu vertikalne, horizontalne i fundamentalne analize $u$ roku od pet godina od poslovanja, utvrdeno je koja se tvrtka najbolje nosila s financijskom krizom. Kroz poslovnu analizu, autori su odredili koja tvrtka ima za cilj poboljšati svoje poslovanje i time postići bolju tržišnu poziciju. Rezultati istraživanja pokazuju da je pozicioniranje odredilo konkurentnost pojedinih tvrtki i njihovu važnost na tržištu te koliko je sama uspješnost povezana s pozicijom koje poduzeće zauzima na tržištu. Prema rezultatima istraživanja PLIVA je tržišni lider; najuspješnija i najsigurnija farmaceutska tvrtka u Republici Hrvatskoj, dok druge tvrtke imaju pozicije sljedbenika, izazivača i tamponera.

Ključne riječi: hrvatsko farmaceutsko tržište, financijska analiza, pozicioniranje na tržištu, analiza radne uspješnosti, farmaceutske kompanije.

JEL klasifikacija: L65, D53

\footnotetext{
Rad je prezentiran na 3. međunarodnoj konferenciji „Business \& Entrepreneurial Economics -BEE2018” u Šibeniku od 30. svibnja do 2. lipnja 2018. (www.bee-conference.com)

4 Dr. sc. Marina Gregorić, viši predavač, Međimursko veleučilište u Čakovcu, Čakovec, Hrvatska, E-mail: marina.gregoric@mev.hr

5 Dajana Maria Horvat, mag. oec., predavač, Međimursko veleučilište u Čakovcu, Čakovec, Hrvatska, E-mail: dajana.maria.horvat@mev.hr

6 Martina Gregorić, MBA Management, direktor, Euro Saturnus Ltd, Zagreb, Hrvatska, E-mail: gregoricm1@gmail.com
} 